\title{
AN ANALYSIS OF STUDENTS' READING COMPREHENSION OF ANALYTICAL EXPOSITION TEXT AT XI IPA 5 OF SMA ADABIAH 2 PADANG AT 2018/2019 ACADEMIC YEAR
}

\author{
ASRUL MULYADIN, RIKA SEPTRIZARTI \\ Administrasi Bisnis, STIA Adabiah \\ asrul_mulyadin@yahoo.com,rikaseptrizarty04@gmail.com
}

\begin{abstract}
Abstrak: Penelitian ini bertujuan untuk mendeskripsikan pemahaman membaca siswa dan kesulitan siswa dalam memahami teks eksposisi analitis di kelas XI IPA 5 SMA Adabiah 2 Padang. Kelas XI IPA 5 dipilih sebagai sampel. Pengumpulan data dilakukan dengan menggunakan tes pemahaman bacaan dan wawancara. Data diuji untuk melihat validitas dan reliabilitas nomor item dan dianalisis secara kuantitatif dan kualitatif. Hasil penelitian menunjukkan bahwa kemampuan pemahaman membaca siswa berada pada taraf sedang. Siswa masih mengalami kesulitan dalam memahami teks eksposisi analitis berdasarkan delapan aspek. Peneliti menemukan lebih banyak masalah dari lima aspek yaitu mengidentifikasi ide utama, makna kosakata dalam konteks, mengidentifikasi referensi, inferensi, tujuan komunikatif yang didukung oleh temuan dari wawancara. Hal ini tersirat bahwa kemampuan siswa dalam memahami teks eksposisi analitis perlu ditingkatkan.
\end{abstract}

Kata kunci: pemahaman bacaan, teks eksposisi analitis.

Abstract: The aims of this research are to describe students' reading comprehension and students' problems in comprehending analytical exposition text at XI IPA 5 of SMA Adabiah 2 Padang. The XI IPA 5 was chosen as the sampel. The data were collected by using reading comprehension test and conducting interview. The data were tested to see the validity and reliability of item numbers and analyzed by using quantitative and qualitative way. The result shows that the ability of students reading comprehension was an average level. The students still have problems in comprehending the analytical exposition text based on eight aspects. The researcher found more problems from five aspects those are identifying main idea, the meaning of vocabulary in the context, identifying reference, inference, communicative purpose that supported by finding from interview. It is implied that students' capability in comprehending analytical exposition text needs to be improved.

Keywords: reading comprehension, analytical exposition text.

\section{A. Introduction}

One of the four skills in English language that should be mastered by the students is reading. Reading becomes very important in the educational field because students can get more information widely and it can increase knowledge without going anywhere. Reading is also an essential skill for English students that they must have ability to understand and comprehend texts assigned to them by the teachers. By having the ability of reading, students will be easy to understand English texts and to get knowledge of what they have read. Basically the purpose of learning to read is to comprehend what it has been read. Considering the reading comprehension, especially for grade XI of senior high school students, they have to be able to comprehend the texts and know the rhetorical steps or generic structure of the texts. There are some indicators of the reading comprehension to reach the purposes such as: 1) identifying the topic as the general subject of reading; 2) identifying the main idea as the "key concept" being expressed, knowing what the author's mean, 3) detailing information to support, clarify, and explain the main idea., 4) guessing words and general information of the text as a mean of the reader to develop students' guessing ability to the word and topic of the text.

Related to explanation above, the researcher found many students have problems in comprehending English texts especially for the second year students of SMA Adabiah 2 
Padang. Even though they have learned English for years, they could not comprehend English texts. It could be influenced by many factors, such as grammar, vocabulary, background knowledge and technique. Then, students also still get problems in finding the topic of what is mainly discussed, main idea, detailed information and reference. It is because students could not activate their background knowledge to the topic discussed to find the new ones from the text. They probably have lack of vocabulary, tend to find out the meaning of word by word from dictionary and translate them into Indonesian while reading the text. This situation makes them bored in reading and passive in the teaching learning process. Moreover, students also have lack of grammar mastery. As an example, most of them cannot differentiate whether the meaning of sentence in active or passive form, whether the event is in the past, presents or future.

Beside has these problems, students still also have difficulties in comprehending the text. One of reading text which should be learnt by students is to comprehend the meaning of short functional texts. Furthermore, in curriculum 2006 competency standard of senior high school, there are many genres to comprehend; they are analytical and hortatory exposition, report, discussion, explanation, procedure, review, narrative, spoof, etc. They are types of which have special characteristics of purpose. It means that they are not only expected to write a text in certain genre but they are required to be able understand some sort of texts. One of genres that is taught at SMA level is analytical exposition text. Analytical exposition text is a written text that is intended to persuade the listeners or readers that something is the case. The researcher chose analytical exposition text for his research because it is one of genres stated in English curriculum for the second grade of SMA students in the first semester It is also one of the difficult genres that students learn in understanding text. Students have difficulties in composing of analytical exposition text, i.e, in identifying thesis statement, arguments and reiteration (restatement) of this text. They still cannot understand what the text tells about, identify the topic and main ideas of this text, and identify generic structure and language feature of the analytical exposition text.

Analytical exposition text is always tested in national examination. Therefore, it is important to be mastered by the students. In national examination, the questions are always related to reading comprehension. In 2016 and 2017, there were 2 texts of expository text which consisted of 8 questions. It shows that the ability in comprehending reading text is very urgent because it influences their successful in answering the questions and passing the final examination. Having these phenomena, the researcher chose students' reading comprehension on analytical exposition text to be analyzed in this research. He found some difficulties that students face in comprehending the text especially for analytical exposition text. For example, the students get difficulties in identifying topic sentence and main idea of the text, meaning of vocabulary, reference and inference. In addition, they also have difficulties in comprehending the texts especially in identifying communicative purpose, generic structure and language features of analytical exposition text. The students get difficulties to identify the generic structure because they have lack ideas to express and explore in argument of this text.

Furthermore, the students have problems in identifying the language features of analytical exposition text. The students should pay attention to control word meaning, phrases, and sentences to get appropriate meaning from the texts. It is related to what language the text uses such as using tenses, modals, adverbs, connective conjunction, etc. In fact, some of the students still don't know how to use it. When the teacher explains to the students, they cannot memorize and differ such as modals and adverbs. All of these facts, it shows that the students still get difficulties to comprehend the text especially in analytical exposition text. Based on the researcher's informal interview with the English teacher of SMA Adabiah 2 Padang, it was found that most of the students get low score in learning English especially reading; it seems difficult for them to comprehend the text, finding the topic, main ideas, vocabulary, reference, and inference etc.

According to Murcia (2001:154) reading is a complex, interactive process involving a text, a reader, and social context in which the activity of reading takes places. Moreover, 
supported by Lines (2005:69) also points out that reading is a set of skills that involves making sense and deriving meaning from the printed word. Then, Grellet (1981:7) states that reading comprehension is an activity to understand a written text. It means extracting the required information from it as efficient as possible. In addition, Giles (1987:95) states that comprehending reading matters involves the correct association of meaning with word, symbols, the evaluating of meanings which are suggested in the context. According to Brown (2004:64) the indicators of reading comprehension as the following: Identifying topic: one thing a text about, main idea: knowing the author's mean, detail: details are used to support, clarify, and explain the main idea, reference to identify the words or phrase to which they refer to, vocabulary is an important part of reading to easy comprehend the reading text, explicit and implicit meaning.

There are two strategies to comprehend reading; they are scanning and skimming. There are some experts give theories about scanning and skimming. Brown (2010:308) states that skimming is the process of fast reading in order to get the gist of a passage. Moreover, he also explains that scanning is the process of quickly searching for particular pieces of information in a text and to extract specific information without reading through the whole text. Supporting points by Adam (1990:69) the skimming technique is a process of reading text quickly. Skimming also requires the ability to comprehend the main idea and supporting detail while reading fast and skipping over selected part whatever is being to read. and scanning is used to know information in advance reader are looking for.

In addition, Harmer (2004:49) also states that "Skimming is speed reading that can save reader's time and help reader get through lots of material quickly. Scanning is very speed for the reader to get specific information". From these theories above, it can be concluded that skimming is fast reading technique to find the general of the text. Meanwhile, scanning can be concluded as the process searching the text quickly to pick out the specific information. Reading difficulty refers to problem associated with reading and it was causing to fall behind in terms of reading requirements within the classroom (Oberholzer, 2005). It means that difficulty in reading comprehension is the problems that are faced by the students in comprehending the text. According to Joseph (2008) when students exhibit difficulty understanding and deriving meaning from text, the explicit instruction on comprehending needs to be provided. Difficulties understanding text can be derived from not knowing meanings of words or concepts, not capturing factual information, not inferring about content, and not forming relationships among content presented in the text.

Spivey (2011) shows that most all texts have one sentence within a paragraph or passage stating the author's message, or main idea. The main idea can appear at the beginning, middle, or end of a paragraph or passage. Finding the main idea becomes more difficult in the upper grades where the main idea may be explicit or implied in the text). Whorter (2014) states that the students learned earlier that the main idea of a paragraph is most important point. The main idea is also the most general statement the writer makes about the topic. In this brief paragraph, the main idea is expressed in the first sentence. This sentence, known as the topic sentence, is the most general statement in the paragraph. All the other sentences are specific details that explain this main idea. Determining a topic and main idea of a text can be one of the problems and difficult tasks in reading comprehension

Analytical exposition is one of the genres that have to be learned by the second grade of senior high schools. It belongs to factual genres in which its function is to make people to take part in a social life. Gerot and Wignell (1995:32) state that analytical exposition text is the text that expands the writer's ideas about the phenomena surrounding us or text that states the introduction of a topic indicating the writer's position in persuading the readers or listeners that something the case. In addition, Amarain (2009:10) state "analytical exposition is a text elaborate, the writer's idea about the phenomena surrounding". They state that analytical exposition is a pieace of text in which some thesis is expounded and argued for. This idea is in line with. Martin and Rothery (2011:8) generalize the generic structure of exposition genre are: 
Thesis, Argument, and Reiteration. In this structure, "thesis" is the part of the text in which the writer states his/her position on the issue, and "argument" is concerned with information provided to justify that position. Finally, "conclusion" is the part of the text where the thesis and arguments can be briefly restated.

\section{B. Research Method}

The research was a descriptive research which mixes the quantitative and qualitative method (mixed method research). It was conducted in SMA Adabiah 2 Padang. The sample of this research was The XI IPA 5. To collect quantitative data the researcher used reading comprehension test, while to collect the qualitative data, the researcher used interview. Reading comprehension test is used to know students comprehension the analytical exposition text. The form of the test was multiple choice tests. Then, the item numbers consist of 35 items.. The questions from the text were based on the reading comprehension indicators.

\section{Result and Discussion}

\section{The Students' Reading Comprehension Of Analytical Exposition Text}

The result could be concluded that: There were 5 students got excellent score and their level was High Ability, 14 students got good score, and 11 students got fair scores and their level was included to Average Ability. Then, 1 student got poor score, and also one student got very poor score and their level was included to Low Ability. Thus, the mean of test score was 69. It means that the students' ability in reading comprehension test of analytical exposition text belongs to Good Categories and average Levels.

The category of students reading comprehension of analytical exposition based on indicators; excellent in identifying topic: good in analyzing main, identifying generic structure and identifying language feature; Fair in identifying vocabulary, identifying social function; poor in identifying reference and identifying inference. The ability of students' reading comprehension of analytical exposition based on indicators; high in identifying topic: average in identifying main idea, vocabulary, reference, social function, and generic structure and identifying language feature; low in identifying inference

\section{The students' problems in comprehending analytical exposition text.}

The result of the test described the result of the students' problem in comprehending analytical exposition text. There were a few students had problems in identifying the topic in the text. They had problem to determine what the text about and the subject under discussion; they didn't comprehend the text. It is supported by the data from interview which said that most of the students know how to identify the topic detail. For analyzing main idea, some of students still had problems in analyzing it in the text. Some of them didn't know the point of author in each paragraph of the text. The students were difficult to find out what they wanted to understand and valued in the text, they just could guess about what the main idea was. It is supported by the data from interview which is said that many of students didn't know how to identify the main idea.

There are almost a half of students had problems in identifying the meaning of the vocabulary in the context. When the researcher gave the test, they still had smaller expensive vocabularies, learning word meanings, use context to identify words but not as efficiently and form a less developed word meanings. Most of students still had no understanding in identifying what the words/sentences were related to each other. Recognize the way in which a text has been organized, but the students didn't understand where it refers to. They didn't know these connections or links. The students also couldn't know pronoun in the text and didn't have meaning themselves but they refer to something else for their meaning. In the other hand, a few students could understand to identify the reference in the text.

For analyzing the inference, the students mostly had problems in making conclusion about the text. They were not able to make information clearly what they were reading. Most of the information they got from reading comes from what is implied rather than direct 
statements as you can see from the amount of information we got from "reading between the lines." For analyzing the social function, most of the students understood what the purpose of the text especially for analytical exposition text. But there were few students still had problem to analyze the purpose or social function of the text.

Next, for analyzing generic structure, it was showed that almost half students had problems couldn't comprehend the generic structure of text. They did not know the position of thesis statement, arguments and reiteration. But more than a half of them could identify this position of text structure. Based on the students results, only a few students had problems couldn't comprehend the language use in this text. It is supported by the data from interview which is said that the students have problems couldn't find the language use in the text., such as modal, mental process verbs, conjunctive enumeration used in it, tenses, and what participant told in the text.

A good comprehension of reading can be indicated by the comprehension of the readers to identify the topic, analyze main idea, find the meaning of vocabulary, and identify reference and inference of the text. That is why the students' comprehension on the text being read can be measured by their ability in identifying the topic, main idea, vocabulary, reference and inference of the text. Reflecting on the first research question, this research found that the students reading comprehension of analytical exposition text belongs to good levels. There are five students got excellent score, fourteen students got good score, eleven students got fair scores, one student got poor score, and one student got very poor score. Based on these results, it also shows that the highest score is identifying topic and the lowest score is analyzing reference

In answering the second research question, researcher found the students' problems in comprehending analytical exposition text based on eight indicators. There were a few students having problems in identifying the topic in the text. They had problem to determine what the text about and the subject under discussion. For analyzing the main idea, some of them didn't know the thought being expressed in each paragraph of the text. There are almost a half of them had problems in identifying the meaning of the word in the context. The students also had problems in reference. Most of them still had no understanding in identifying what the words/sentences were related to each other.

For analyzing the inference, the students mostly had problems in making conclusion about the text. Most of information they got from reading comes from what is implied rather than direct statements. For analyzing the social function there were few students still had problem to analyze the purpose or social function of the text. Next, for analyzing generic structure, almost half of them had problem couldn't identify the position of text structure. And only a few students have problems in identifying language feature.

\section{Conclusion}

Based on the result of data analysis and findings of this research which was conducted at XI IPA 5 of SMA Adabiah 2 Padang it can be drawn several conclusion. First, that students' reading comprehension is categorized good based on the mean of the students' result in comprehending reading of analytical exposition text. Second, from the data analysis above, it explained that most of students had problems in some aspects of comprehending analytical exposition text. But the big problem is identifying reference it was poor categorized

\section{References}

Adam, W. Royce. 1990. Reading Skill: A Guide for Better Reading. New York: Macmillan Amarain, Shirin. 2009. Text Forms and Features. Jakarta: Umbrella Corporation.

Becky L. Spivey, M.E.d, (2011), what's the big idea? Finding and understanding the main Idea, free Educational handouts for teacher and parents

Brown, H. Douglas. 2004. Strategies for Success: A Practical Guide to Learning English. New York: Longman. 
Gerot, L.R and P. Wignell.1995. Making Sense of Functional Grammar. Sydney: Antipodean Educational Enterprise

Giles, Jim. 1987. The English Hand Book. New Jersey: Publication Branch

Grellet, Francoise. 1998. Developing Reading Skills: A Practical Guide to Reading Comprehension Exercises. Cambridge: Cambridge University Press

Harmer, Jeremy. 1998. How to Teach English. New York: Pearon Education Limited

Laurice M. Joseph. 2008, Best practices on interventions for students with reading problems, The Ohio State University, Best practice in school psychology V, page : 1172, Chapter 71 volume 4

Lines, Caroline T. 2005. Practical English Language Teaching: Young Learners. New York: MCGraw-Hill Companies, Inc

Martin, R and Y. Rothery. 2011Analitycal Exposition Text Retrieved on May, 202013 from http://www.drkevintblake.com/analytical exposition text.pdf.York \& London: Lawrence Erlbaum Associates

Mc whorter. 2014, Topics, Main idea, and Topic Sentences, Page : 150 For Adult Learning and Literacy, Volume 1: Chapter Two

Murcia, C. Marianne. 2001. Teaching English as Second or Foreign Language. Los Angeles: University of California.

Oberholzer, B. 2005. The Relationship between Reading Difficulties and Academic Performance (Submitted in part fulfiIment of the requirements for the degree of $\mathrm{M} \mathrm{Ed}$ (Ed. Psych). (Online). Vol. xii, 119 leaves. University of Zululand's Library Catalogue. (http://uzspace.uzulu.ac.za/handle/10530/398). Accessed on 30th August, 2015. 